\title{
Identification of a novel source of resistance to angular leaf spot disease of common bean within the secondary gene pool
}

\author{
J. P. Busogoro ${ }^{1}$, M. H. JiJAKLi ${ }^{1}$ and P. LePoivre ${ }^{1,2}$ \\ ${ }^{1}$ Faculté Universitaire des Sciences Agronomiques de Gembloux, Unité de Phytopathologie, 2, Passage des Déportés, \\ B-5030 Gembloux, Belgium; ${ }^{2}$ Corresponding author \\ With 3 figures and 3 tables \\ Received February 20, 1999/Accepted July 1, 1999 \\ Communicated by B. Schweisguth
}

\begin{abstract}
Phaeoisariopsis griseola (Sacc.) Ferr., the agent of angular leaf spot disease of common bean, is a highly variable pathogen for which resistance gene diversification is required. This study analysed genetic resistance to this disease within genotypes of three Phaseolus species. Twentynine genotypes of Phaseolus vulgaris, Phaseolus coccineus and Phaseolus polyanthus were inoculated with 54 isolates of Phaeoisariopsis griseola. The genetic resistance was estimated according to the symptom intensity observed for each plant genotype-pathogen isolate combination. Globally, genotypes of the common bean secondary gene pool were resistant to a higher number of isolates than common bean varieties Interactions between plant genotypes and pathogen isolates suggested vertical resistance genes within $P$. vulgaris, as well as within $P$. coccineus and $P$. polyanthus. The 'NI666' accession ( $P$. coccineus) showed resistance to all the fungal isolates inoculated while the variety 'Aroana' $(P$. vulgaris) was susceptible to most of the isolates. Interspecific hybridization between these two genotypes gave $F_{1}$ hybrid plants which showed resistance to angular leaf spot disease.
\end{abstract}

Key words: Phaeoisariopsis (Isariopsis) griseola - Phaseolus coccineus - P. polyanthus - P. vulgaris - angular leaf spot resistance - secondary gene pool

The angular leaf spot (ALS) disease of common bean caused by Phaeoisariopsis griseola (Sacc.) Ferr. (Isariopsis griseola Sacc.) (Cardona-Alvarez and Walker 1956) induces yield losses which can reach $80 \%$ under severe conditions of infection (Schwartz et al. 1981).

Many control strategies, including chemical applications (Bhardwaj et al. 1994), cultural practices (Correa et al. 1989) and genetic resistance, (Schwartz et al. 1982) can be used for the management of ALS. Genetic resistance appears to be the most appropriate method for the subsistence agriculture prevailing in developing countries because of the limited finances of the farmers. The main drawback of this method is possible resistance breakdown (Brown 1994) caused by pathogen adaptation to the host resistance (Fry 1982, Chen et al. 1993, McDermott 1993).

Some evidence of pathogenic variability in Phaseolus griseola have been shown based on pathogenicity in differential cultivars (Alvarez-Ayala and Schwartz 1979) and on RAPD patterns (Guzmán et al. 1995). Within 54 P. griseola isolates inoculated on 29 plant genotypes, we revealed 53 different virulence profiles (Busogoro et al. 1999). Despite the absence of known sexuality, $P$. griseola has to be considered as a highly variable pathogen and ALS disease management by genetic resistance must take into account this diversity. In fact, in India, Srivastava et al
(1995) identified different resistant lines in common bean, which appeared susceptible after 2 or 3 years, suggesting a possible resistance breakdown related to pathogen adaptation. In Africa, Aggarwal et al. (1996) described a Phaseolus vulgaris line showing resistance to ALS in Tanzania, Zimbabwe and South Africa, while it was susceptible in Uganda.

Thus, diversification of resistance genes and a rational strategy of resistance gene deployment are necessary for disease management. In this respect, possible sources of resistance to ALS within other Phaseolus species are not well known. Resistance genes to ALS were mainly reported within the $P$. vulgaris species (Correa et al. 1989, Beebe and Pastor-Corrales 1991). Only the study of Singh and Saini (1980) describes resistance to ALS identified within a $P$. coccineus genotype. Species within the secondary gene pool ( $P$. coccineus and $P$. polyanthus) are already known to have interesting agronomic traits such as resistance to Ascochyta leaf spot and golden mosaic virus (Schmit et al. 1993).

The objective of this study was to find novel sources of resistance to ALS by analysing genotypes which belong to the secondary gene pool of $P$. vulgaris.

\section{Materials and Methods}

Plant genotypes: Inoculation tests were performed on 29 plant genotypes (Table 1) containing 17 varieties of $P$. vulgaris, six accessions of $P$. coccineus and six accessions of $P$. polyanthus. Among these genotypes, only two wild accessions of $P$. coccineus ('NI1108' and 'NI819') are not used as current cultivars.

Pathogen isolates: A collection of 54 P. griseola isolates was obtained from naturally infected bean leaves and cultured on V8 juice agar medium (per litre: $200 \mathrm{ml} \mathrm{V8,} 3 \mathrm{~g} \mathrm{CaCO}_{3}$ and $18 \mathrm{~g}$ agar) kept in the dark at $\pm 20^{\circ} \mathrm{C}$. Colonies produced from single spores were conserved in a cold room $\left(4{ }^{\circ} \mathrm{C}\right)$ as pure isolates for inoculation tests. Forty-four isolates originated from Central African countries (Burundi, Rwanda, Zaire and Kenya) while 10 isolates were collected in Brazil and Colombia (Table 2).

Inoculation tests: Conidia were harvested from 12-day-old cultures grown on V8 agar medium, suspended in distilled water and adjusted to a concentration of $2 \times 10^{4}$ conidia $/ \mathrm{ml}$. Inoculations were performed on the first trifoliate leaves by spraying the inoculum to run-off under a pressure of $2.8 \mathrm{~kg} / \mathrm{cm}^{2}$ until saturation.

Inoculated plants (three per each 'isolate $\times$ genotype' combination) were incubated for 4 days in a humid chamber (relative humidity $95 \%$ ) at $25^{\circ} \mathrm{C}$ with a 16 -h photoperiod. Plants were then maintained in greenhouse and symptom intensity was scored according to the visual scale 
Table 1: List of Phaseolus vulgaris, Phaseolus coccineus and Phaseolus polyanthus genotypes evaluated for their resistance to angular leaf spot disease

\begin{tabular}{|c|c|c|c|}
\hline Number & Genotype & Species & Origin \\
\hline 1 & 'BAT76' & P. vulgaris & ISABU $^{1}$ \\
\hline 2 & 'Calima' & P. vulgaris & ISABU \\
\hline 3 & 'Aroana' & P. vulgaris & ISABU \\
\hline 4 & 'A340' & P. vulgaris & ISABU \\
\hline 5 & 'A345' & P. vulgaris & ISABU \\
\hline 6 & 'A285' & P. vulgaris & ISABU \\
\hline 7 & 'A410' & P. vulgaris & ISABU \\
\hline 8 & 'A140' & P. vulgaris & ISABU \\
\hline 9 & 'Prelude' & P. vulgaris & Used in Belgium \\
\hline 10 & 'BAT1647' & P. vulgaris & CIAT $^{2}$ \\
\hline 11 & 'Seafarer' & P. vulgaris & CIAT \\
\hline 12 & 'Cornell49242' & P. vulgaris & CIAT \\
\hline 13 & 'Montcalm' & P. vulgaris & CIAT \\
\hline 14 & 'A339' & P. vulgaris & CIAT \\
\hline 15 & 'G5686’' & P.vulgaris & CIAT \\
\hline 16 & 'BAT332' & P. vulgaris & CIAT \\
\hline 17 & 'Pompadous Checa' & P.vulgaris & CIAT \\
\hline 18 & 'N115' & $P$. coccineus & Rwanda \\
\hline 19 & 'NI16' & P. coccineus & Rwanda \\
\hline 20 & 'NI1108' & P. coccineus & Mexico $^{3}$ \\
\hline 21 & 'NI819' & P. coccineus & Mexico $^{3}$ \\
\hline 22 & 'NI229' & P. coccineus & Zaire \\
\hline 23 & 'NI666' & P. coccineus & Porto Rico \\
\hline 24 & 'NI429' & P. polyanthus & Costa Rica \\
\hline 25 & 'NI519' & P. polyanthus & Mexico \\
\hline 26 & 'NI1208' & P. polyanthus & Colombia \\
\hline 27 & 'NI1010' & P. polyanthus & Colombia \\
\hline 28 & 'NI1011' & P. polyanthus & Colombia \\
\hline 29 & 'NI373' & P. polyanthus & Venezuela \\
\hline
\end{tabular}

${ }^{1}$ ISABU $=$ Institut des Sciences Agronomiques du Burundi.

${ }^{2}$ CIAT $=$ Centro Internacional de Agricultura Tropical.

${ }^{3}$ Wild genotypes. defined by the CIAT (1992) 16 days after inoculation. The percentage of infected leaf area was evaluated and scored from 1 (if no visible lesion was observed) to 9 (if more than $25 \%$ of the leaf area was covered by disease lesions).

Interspecific crossing: The genotype 'Aroana', a highly susceptible variety of $P$. vulgaris, was hybridized with genotype 'NI666', an accession of $P$. coccineus, the $P$. vulgaris variety being used as the female parent. The pollen was harvested from one plant of the genotype 'NI666'. The hybrid status of plants obtained after this intercrossing process was evaluated based on morphological traits (germination type and stem pigmentation) and molecular patterns. For molecular characterization, random amplified polymorphic DNAs (RAPDs) were performed with the OPK9 primer (Operon Technologies, USA) on total DNA extracted according to the method of Doyle and Doyle (1990) from plants of the two parental genotypes and one plant obtained after interspecific crossing. Amplification reactions were performed in a thermocycler (Biometra TRIO-Thermoblock) where a first DNA denaturation at $94^{\circ} \mathrm{C}$ for $3 \mathrm{~min}$ was followed by 45 cycles of $1 \mathrm{~min}$ at $94^{\circ} \mathrm{C}, 1 \mathrm{~min}$ at $35^{\circ} \mathrm{C}$ and 2 min at $72^{\circ} \mathrm{C}$. A final elongation step was carried out at $72^{\circ} \mathrm{C}$ for $10 \mathrm{~min}$. The reaction mixture was a $50 \mu \mathrm{l}$ final volume containing $5 \mu \mathrm{l}$ of the polymerase chain reaction (PCR) reaction buffer $10 \times$ concentrated (Boehringer Mannheim, Germany), $0.4 \mu \mathrm{M}$ OPK 9 primer, $4 \mathrm{mM} \mathrm{MgCl} 2,200 \mu \mathrm{M}$ of each dNTP, $50 \mathrm{ng}$ of total DNA and 1 unit of Taq polymerase (Boehringer Mannheim). Electrophoretic analysis of amplified products was performed in a $1.5 \%$ agarose gel stained by ethidium bromide and observed under UV light. Six plants, randomly chosen among the nine progenies obtained by the interspecific crossing, were inoculated with the isolate KGM6.

Data analysis: Symptom intensity, scored according to the CIAT (1992) scale, allowed the plant reaction type (RT) to be determined: resistance ( $\mathrm{R}$ if symptom score $\leqslant 3$ ), partial resistance ( $\mathrm{PR}$ if $3<$ symptom score $\leqslant 6$ ) and susceptibility ( $\mathrm{S}$ if $6<$ symptom score $\leqslant 9$ ). In cases of susceptibility or partial resistance reaction of plant genotypes, isolates were considered as virulent while in cases of resistance reaction, they were considered as avirulent. Plant genotypes were compared according to their respective number of avirulent isolates.

These RT were recorded in a matrix and analysed by hierarchical cluster analysis using the average linkage method with the statistical program SYSTAT version 5 . The distances between plant genotypes, which were calculated as the percentage of isolates causing dissimilar reaction types, were shown in a dendrogram derived from this analysis.

\section{Results}

The genotype 'NI666', an accession of $P$. coccineus, was resistant to all the inoculated isolates while genotype 'Aroana', a variety of $P$. vulgaris, was susceptible to 48 pathogen isolates. Three categories of RT (resistance, partial resistance and susceptibility) were observed on some other plant genotypes according to the inoculated isolates. For example, the genotype 'BAT76' appeared resistant with isolate KGR1 and partly resistant with isolate $\mathrm{KGM} 1$, but susceptible with the isolate KGM2. This interaction profile was revealed for common bean genotypes as well as for the secondary gene pool genotypes.

Table 3 shows the reaction type of each plant genotype inoculated with the different fungal isolates. Cluster analysis allowed the genotypes to be grouped according to their respective reactions after inoculation by the 54 isolates (Fig. 1). The greatest distance on the dendrogram $(63 \%)$ allowed separation of most of the P. vulgaris genotypes from the accessions of $P$. coccineus and $P$. polyanthus and the recognition of two main groups of genotype. One of these groups contains only $P$. vulgaris material 
Table 2: List of Phaeoisariopsis griseola isolates inoculated on the 29 plant genotypes for the evaluation of the genetic resistance

\begin{tabular}{|c|c|c|c|c|c|}
\hline Number & Isolate & Origin Country & Location & Collection date & Sent by \\
\hline 1 & KGM1 & Burundi & Muhingira & January 1994 & ISABU \\
\hline 2 & KGM2 & Burundi & Muhingira & January 1994 & ISABU \\
\hline 3 & KGM3 & Burundi & Muhingira & January 1994 & ISABU \\
\hline 4 & KGM4 & Burundi & Muhingira & January 1994 & ISABU \\
\hline 5 & KGM5 & Burundi & Muhingira & January 1994 & ISABU \\
\hline 6 & KGM6 & Burundi & Muhingira & January 1994 & ISABU \\
\hline 7 & KGM7 & Burundi & Muhingira & January 1994 & ISABU \\
\hline 8 & KGM8 & Burundi & Muhingira & January 1994 & ISABU \\
\hline 9 & KGR1 & Burundi & Rubagabaga & January 1994 & ISABU \\
\hline 10 & KGR2 & Burundi & Rubagabaga & January 1994 & ISABU \\
\hline 11 & KGR3 & Burundi & Rubagabaga & January 1994 & ISABU \\
\hline 12 & KGR4 & Burundi & Rubagabaga & January 1994 & ISABU \\
\hline 13 & KGR5 & Burundi & Rubagabaga & January 1994 & ISABU \\
\hline 14 & KGR6 & Burundi & Rubagabaga & January 1994 & ISABU \\
\hline 15 & NMM1 & Burundi & Murama & January 1994 & ISABU \\
\hline 16 & NMM2 & Burundi & Murama & January 1994 & ISABU \\
\hline 17 & NMM3 & Burundi & Murama & January 1994 & ISABU \\
\hline 18 & KF1 & Kenya & Unknown & April 1994 & University of Nairobi \\
\hline 19 & FK4 & Kenya & Unknown & April 1994 & University of Nairobi \\
\hline 20 & KK1 & Burundi & Kabuye & July 1994 & ISABU \\
\hline 21 & KK2 & Burundi & Kabuye & July 1994 & ISABU \\
\hline 22 & KK3 & Burundi & Kabuye & July 1994 & ISABU \\
\hline 23 & KK4 & Burundi & Kabuye & July 1994 & ISABU \\
\hline 24 & KK5 & Burundi & Kabuye & July 1994 & ISABU \\
\hline 25 & KK6 & Burundi & Kabuye & July 1994 & ISABU \\
\hline 26 & RN1 & Colombia & Rio Negro & February 1994 & CIAT \\
\hline 27 & RN2 & Colombia & Rio Negro & February 1994 & CIAT \\
\hline 28 & RN4 & Colombia & Rio Negro & February 1994 & CIAT \\
\hline 29 & RN8 & Colombia & Rio Negro & February 1994 & CIAT \\
\hline 30 & RN10 & Colombia & Rio Negro & February 1994 & CIAT \\
\hline 31 & BR1 & Brazil & Goiás & December 1995 & EMBRAPA $^{1}$ \\
\hline 32 & $\mathrm{BR} 2$ & Brazil & Ceará & December 1995 & EMBRAPA \\
\hline 33 & $\mathrm{BR} 3$ & Brazil & Minas Gerais & December 1995 & EMBRAPA \\
\hline 34 & $\mathrm{BR} 4$ & Brazil & Espírito Santo & December 1995 & EMBRAPA \\
\hline 35 & BR5 & Brazil & Pernambuco & December 1995 & EMBRAPA \\
\hline 36 & RDA1 & Rwanda & Unknown & April 1996 & University of Rwanda \\
\hline 37 & RDA2 & Rwanda & Unknown & April 1996 & University of Rwanda \\
\hline 38 & RDA3 & Rwanda & Unknown & April 1996 & University of Rwanda \\
\hline 39 & RDA6 & Rwanda & Unknown & April 1996 & University of Rwanda \\
\hline 40 & RDA7 & Rwanda & Unknown & April 1996 & University of Rwanda \\
\hline 41 & BGA2 & Burundi & Gitega & April 1996 & University of Burundi \\
\hline 42 & BGA4 & Burundi & Gitega & April 1996 & University of Burundi \\
\hline 43 & BGA5 & Burundi & Gitega & April 1996 & University of Burundi \\
\hline 44 & ZA1 & Zaire & Unknown & May 1996 & University Kinshasa \\
\hline 45 & ZA2 & Zaire & Unknown & May 1996 & University Kinshasa \\
\hline 46 & ZA3 & Zaire & Unknown & May 1996 & University Kinshasa \\
\hline 47 & ZA4 & Zaire & Unknown & May 1996 & University Kinshasa \\
\hline 48 & ZA5 & Zaire & Unknown & May 1996 & University Kinshasa \\
\hline 49 & ZA6 & Zaire & Unknown & May 1996 & University Kinshasa \\
\hline 50 & ZA7 & Zaire & Unknown & May 1996 & University Kinshasa \\
\hline 51 & ZA8 & Zaire & Unknown & May 1996 & University Kinshasa \\
\hline 52 & ZA9 & Zaire & Unknown & May 1996 & University Kinshasa \\
\hline 53 & ZA10 & Zaire & Unknown & May 1996 & University Kinshasa \\
\hline 54 & ZA11 & Zaire & Unknown & May 1996 & University Kinshasa \\
\hline
\end{tabular}

${ }^{1}$ EMBRAPA: Empresa Brasileira de Pesquisa Agropecuaria.

(12 genotypes) among which the cultivar 'Aroana' appeared susceptible to the largest number of isolates. The second group contains all the accessions of $P$. coccineus and $P$. polyanthus, including 'NI666', which appeared resistant to all the inoculated isolates. Only five genotypes of $P$. vulgaris were grouped together with the most resistant genotype, 'NI666'.

Figure 2 compares the frequency of genotypes belonging to $P$. vulgaris or to the secondary gene pool according to the number of avirulent isolates per genotype. Globally, genotypes of $P$. coccineus and $P$. polyanthus appeared resistant to a larger number of $P$. griseola isolates than genotypes belonging to $P$. vulgaris. The mean number of avirulent isolates per genotype was equal to 37 for the secondary gene pool genotypes and 20 for the P. vulgaris genotypes.

Genotype 'NI666', which appeared resistant to all 54 isolates, was crossed with the susceptible cultivar 'Aroana'. The nine plants resulting from intercrossing appeared to be intermediate between the two parental genotypes in terms of morphological traits, such as germination type (epigeal for 'Aroana' and hypogeal for 'NI666') and stem pigmentation (greenish for 'Aroana' and reddish for 'NI666'). The intermediate character of these plants was confirmed by molecular analysis. The RAPD pat- 


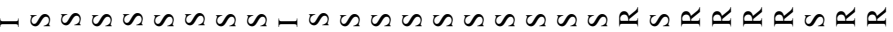

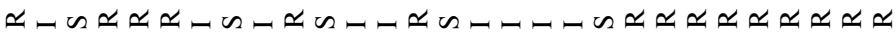

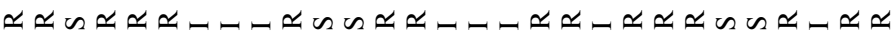

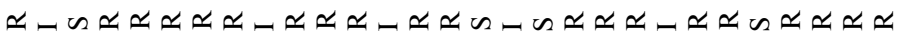

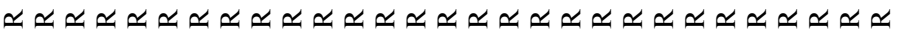

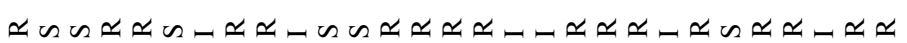

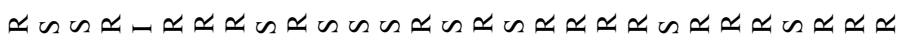

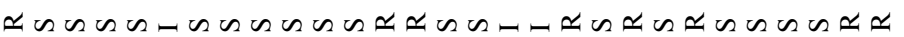

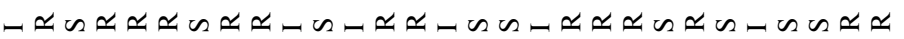

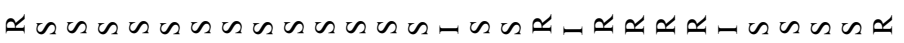

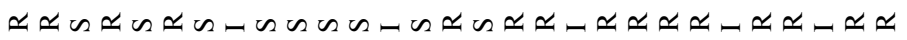

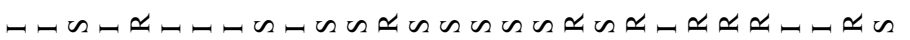

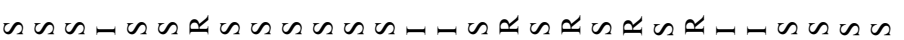

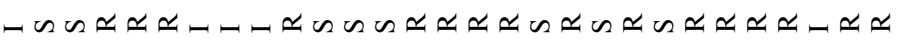

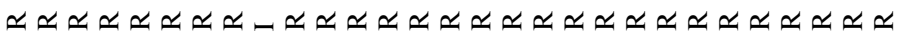

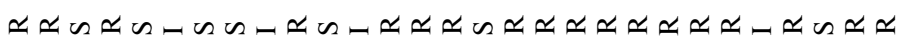

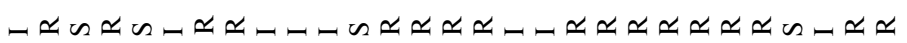

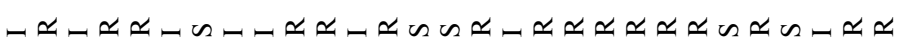

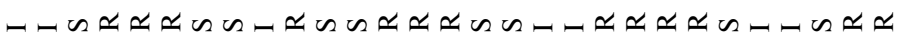

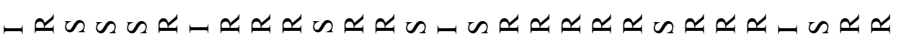

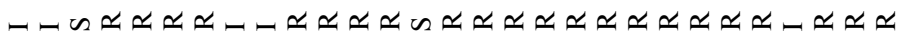

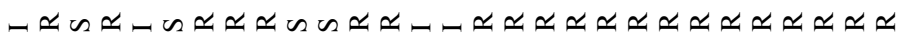

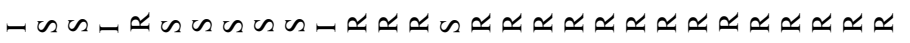

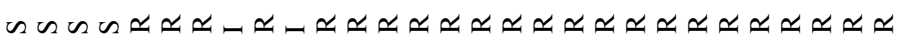
$\neg \simeq \sim \sim \sim \simeq \sim \simeq \simeq \sim \simeq \sim \simeq \simeq \simeq \sim \sim \sim \simeq \simeq \simeq \simeq \simeq \simeq \simeq \simeq \simeq \simeq$

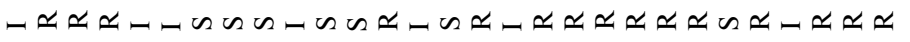

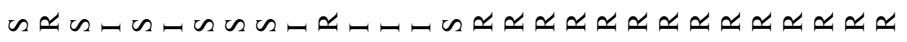

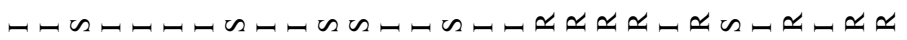

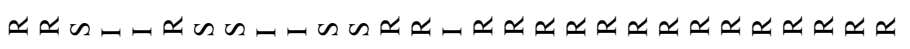

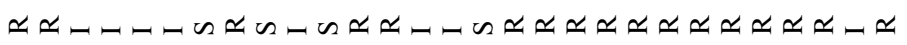

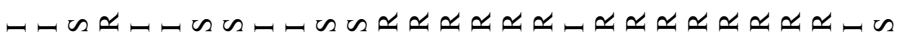

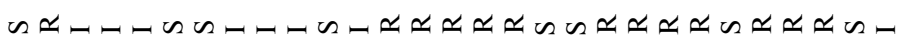

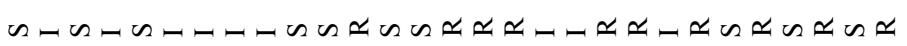

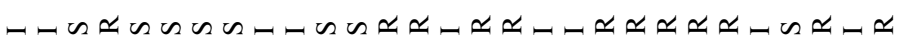

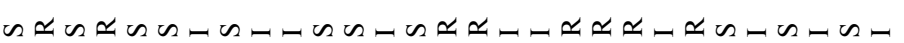

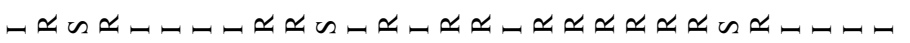

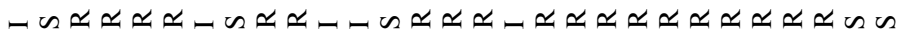

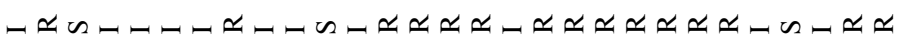

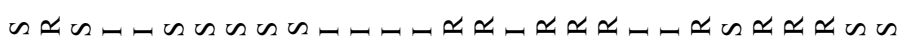

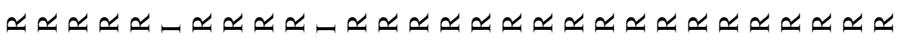

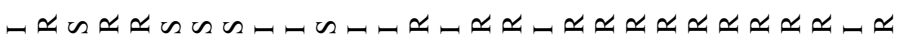

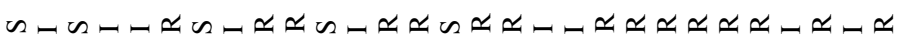

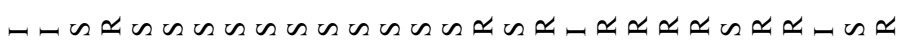

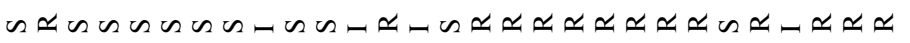

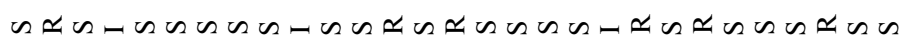

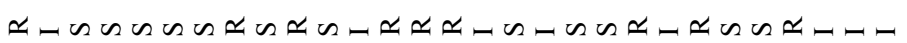

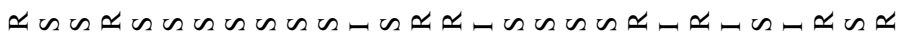

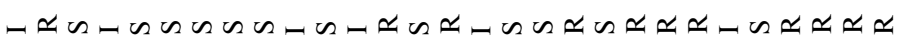

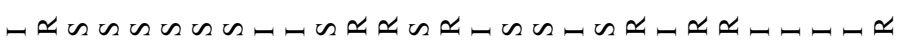

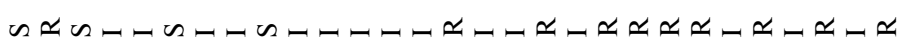

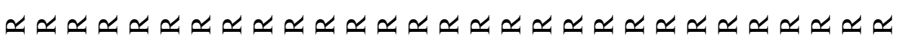

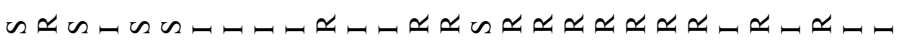

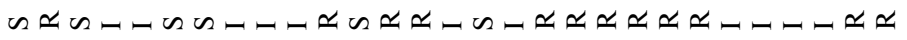

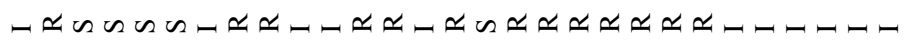



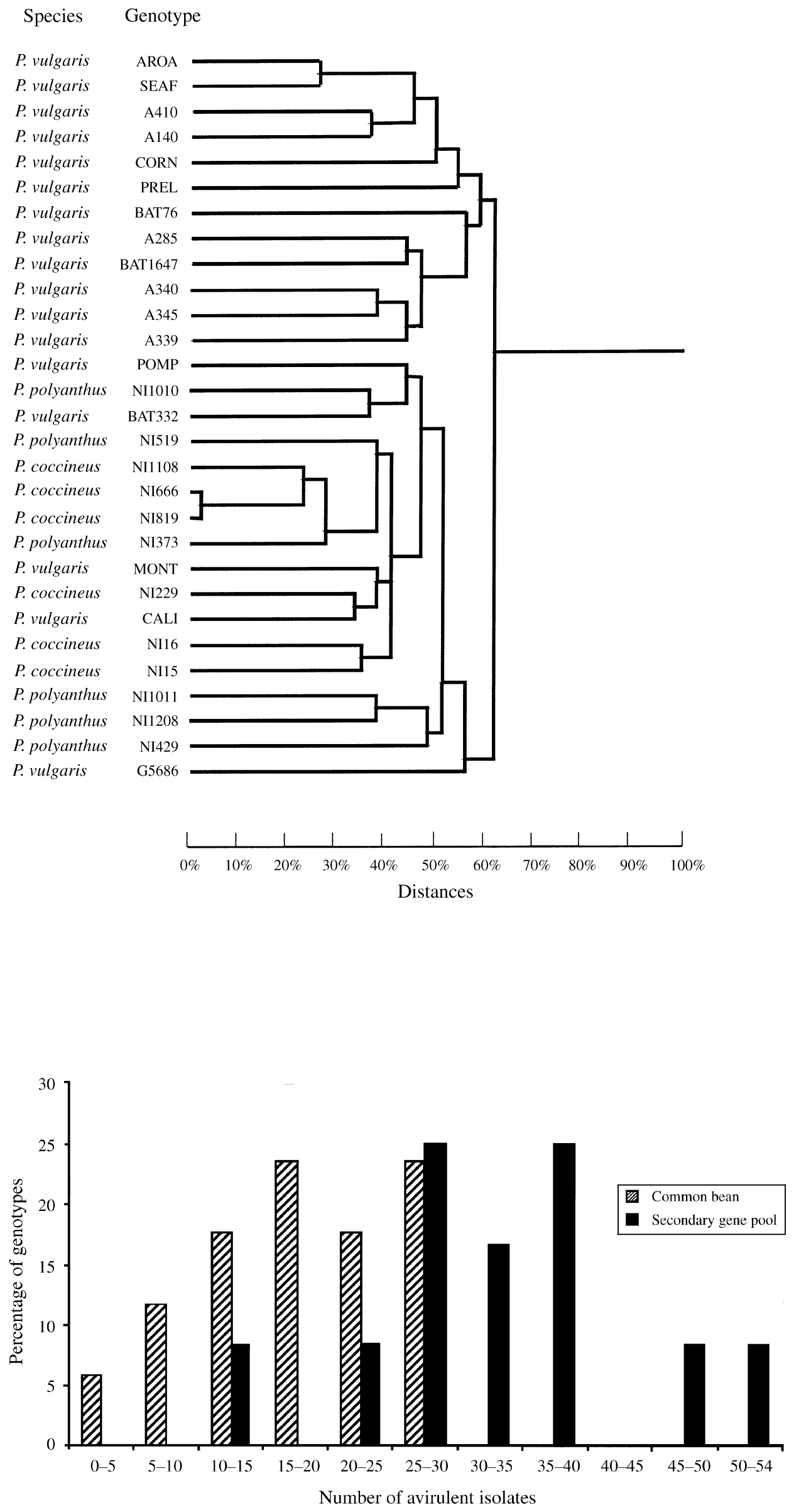

Fig. 1: Tree diagram of the 29 Phaseolus genotypes based on the infection types showed after inoculation by the 54 pathogen isolates. Cluster analysis is performed according to three infection types (resistance, partial resistance and susceptibility). Distances between two genotypes are calculated as the percentage of isolates for which genotypes exhibit different infection types
Fig. 2: Analysis of genotype resistance estimated by the number of avirulent pathogen isolates. An isolate was considered as avirulent if it caused a resistance reaction and virulent if it caused a susceptibility or a partial resistance reaction 


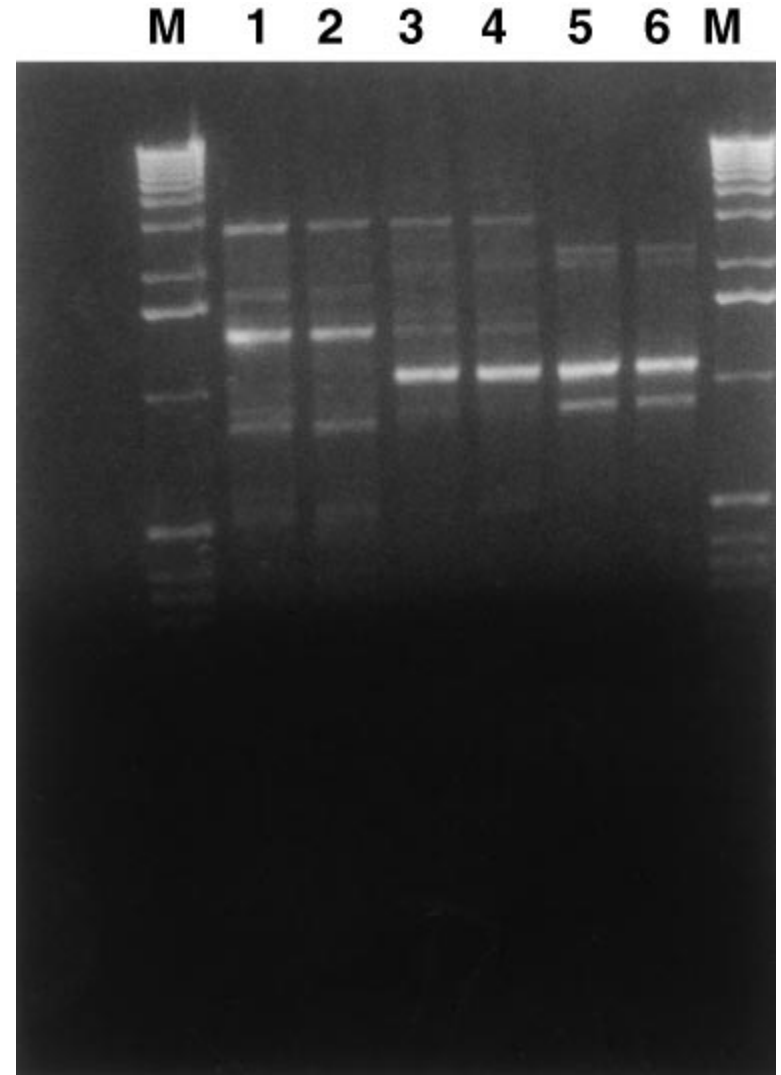

Fig. 3: Agarose-gel (1.5\%) electrophoresis and staining with ethidium bromide of the RAPD amplified fragments from total DNA of the two parental genotypes (lanes 1 and 2 for 'Aroana'; lanes 5 and 6 for 'NI666') and the hybrid plant (lanes 3 and 4). M: lanes with molecular size marker (100 bp)

terns of each parental genotype exhibited specific bands which were not observed in the other parental genotype patterns, while specific bands of both parents were observed on the patterns obtained for one of the plants resulting from interspecific hybridization (Fig. 3). Inoculation tests performed with the isolate KGM6 (virulent on 'Aroana' and avirulent on 'NI666') gave rise to resistance reactions on all inoculated interspecific progenies (six), as was the case for the 'NI666' control plants and in contrast to the 'Aroana' control plants. All these hybrid plants died before flowering, suggesting a physiological deficiency for the interspecific hybridization between genotypes 'Aroana' and 'NI666'.

\section{Discussion}

The inoculation tests have shown differential interactions between plant genotypes and P. griseola isolates. These interactions, observed both with $P$. vulgaris and its secondary gene pool ( $P$. coccineus and $P$. polyanthus), suggest the presence of vertical resistance genes (Nelson 1978). Our observations showed that such race-specific genes can be found within $P$. vulgaris, but equally within its secondary gene pool. Globally, genotypes of $P$. coccineus and $P$. polyanthus have shown resistance to more $P$. griseola isolates than genotypes of common bean. This observation should be treated with caution because genotypes of $P$. vulgaris used for the present study were mostly improved varieties and thus, not perfectly representative of the diversity of this species.
In the past, Saettler and Correa (1984) observed differential interactions between bean lines and P. griseola isolates. Different work, demonstrating interactions between bean genotypes and $P$. griseola isolates, as well as resistance to ALS controlled by single genes, were summarized by Beebe and Pastor-Corrales (1991). For diseases caused by variable pathogens like bean ALS (Schwartz et al. 1982, Guzmán et al. 1995, Chacón et al. 1997), it is necessary to diversify the sources of resistance (Young and Kelly 1996, Wehner and Shetty 1997). Identification of genotypes with resistance to ALS within the secondary gene pool could contribute to this management strategy.

Such resistances to common bean diseases were frequently found within secondary gene pool genotypes. For example, a resistance to common bacterial blight has been identified within a line of P. coccineus (Welsh and Grafton 1997). Beebe and Pastor-Corrales (1991) indicated resistance to bean golden mosaic virus within accessions of $P$. coccineus and resistance to bean anthracnose within accessions of $P$. polyanthus.

Resistance genes within secondary gene pool genotypes might be transmitted to common bean genotypes because of the feasibility of interspecific hybridization (Baudoin and Maréchal 1985). In our work, feasibility of interspecific transfer of resistance to P. griseola in common bean was analysed. Germination type, a property which allows one to differentiate $P$. vulgaris from P. coccineus species (Anderson and Ascher 1996), as well as the stem pigmentation, which was equally different between the two genotypes crossed, were considered. The intermediate morphological traits of plants resulting from the interspecific hybridization suggested that these were $F_{1}$ hybrid plants. The RAPD pattern shown by one of the hybrid plants was intermediate between the two parental genotypes.

Resistance reactions observed for the $\mathrm{F}_{1}$ hybrid plants proved the possible transfer of resistance from the $P$. coccineus genotype ('NI666') to common bean varieties. Singh and Saini (1980) described an ALS resistance gene transferred from a $P$. coccineus genotype to a $P$. vulgaris variety. This resistance was controlled by a recessive factor because all the $F_{1}$ plants were susceptible while there was a 3:1 ratio of segregation at the $F_{2}$ generation. Recently, Welsh and Grafton (1997) were able to transfer resistance to common bacterial blight from $P$. coccineus to $P$. vulgaris. In our work, the resistance might be controlled by nuclear factors since the resistant parent was used as the male. More precise characterization of this resistance would come from an analysis of the segregation of the resistance in later generations. This type of analysis presents limitations for the crossing performed in our study because of the physiological deficiency in the hybrid plants. In order to overcome these limitations, reverse crossing could be tried between the two genotypes, despite the fact that having $P$. coccineus as the female parent is very difficult (Singh and Saini 1980). Another possibility would be to find common bean genotypes more compatible with the genotype 'NI666' than the cv. 'Aroana'. These genotypes could be used to transfer the resistance identified to the common bean species. Hybridization using $P$. polyanthus as a bridge species might also overcome the limitations of $P$. vulgaris $\times P$. coccineus intercrossing because $P$. polyanthus is closer to P. vulgaris than P. coccineus (Schmit et al. 1993).

\section{Acknowledgement}

The authors thank Dr J. P. Baudoin, Tropical Crop Husbandry Unit of the Agricultural University of Gembloux, Belgium, for providing $P$. coccineus and $P$. polyanthus seeds. 


\section{References}

Aggarwal, V. D., C. M. Jambawe, R. M. Chirwa, and C. T. Kisyombe, 1996: Identification of a multiple disease resistant line from the Andean gene pool. Annu. Rep. Bean Improve. Coop. 39, 282-283.

Alvarez-Ayala, G., and H. F. Schwartz, 1979: Preliminary investigations of pathogenic variability expressed by Isariopsis griseola. Annu. Rep. Bean Improve. Coop. 22, 86-87.

Anderson, N. O., and P. D. Ascher, 1996: Morphological and biochemical variability in two-species congruity backcross (CBC) Phaseolus vulgaris $\times P$. coccineus hybrids. Annu. Rep. Bean Improve. Coop. 39, $120-121$.

Baudoin, J. P., and R. Maréchal, 1985: Genetic diversity in Vigna. In: R. S. Singh, and K. O. Rachie (eds), Cowpea Research. Production and Utilization, 3-9. John Wiley and Sons, London.

Beebe, E., and M. Pastor-Corrales, 1991: Breeding for disease resistance. In: A. van Schoonhoven, and O. Voyset (eds), Common Beans: Research for Crop Improvement, 561-617. CAB Int., Wallingford.

Bhardwaj, C. L., S. C. Nayital, S. Verma, and N. R. Kalia, 1994: Effect of sowing date, variety and management of angular leaf spot (Phaeoisariopsis griseola) on yield of French bean (Phaseolus vulgaris). Indian J. Agricult. Sci. 64, 336-338.

Brown, J. K. M., 1994: Molecular and population genetics of barley powdery mildew. In: M. J. Daniels, J. A. Downie, and A. E. Osbourn (eds), Advances in Molecular Genetics of Plant-Microbe Interactions, Vol. 3, 191-198. Kluwer Academic Publ., Dordrecht.

Busogoro, J. P., M. H. Jijakli, and P. Lepoivre, 1999: Virulence variation and RAPD polymorphism in African isolates of Phaeoisariopsis griseola (Sacc.) Ferr., the causal agent of angular leaf spot of common bean. Eur. J. Plant Pathol. (in press).

Cardona-Alvarez, C., and J. C. Walker, 1956: Angular leaf spot of bean. Phytopathology 46, 610 - 615.

Chacón, M. I., C. Jara, G. Castellanos, C. E. Posso, R. Buruchara, J. B. Cuasquer, and M. A. Pastor-Corrales, 1997: Genetic diversity and relation between Common Bean Angular Leaf Spot fungus isolates from Africa and South America: genetic improvement implications. Annu. Rep. Bean Improve. Coop. 40, 127-128.

Chen, X., R. F. Line, and H. Leung, 1993: Relationship between virulence variation and DNA polymorphism in Puccinia striiformis. Phytopathology 83, 1489-1497.

CIAT, 1992: Système standard pour l'évaluation du germoplasme du haricot. In: A. Schoonhoven, and M. A. Pastor-Corrales, (eds), Centro Internacional de Agricultura Tropical, Cali.

Correa, V. F., M. A. Pastor Corrales, and A. W. Saettler, 1989: Angular leaf spot. In: H. F. Schwartz, and M. A. Pastor Corrales (eds),
Bean Production Problems in the Tropics, 2nd edn, 59-75 Centro International de Agricultura Tropical, Cali.

Doyle, J. J., and J. L. Doyle, 1990: Isolation of plant DNA from fresh tissue. Focus 12, 13-15.

Fry, W. E., 1982: Principles of Plant Disease Management. Academic Press, London.

Guzmán, P., R. L. Gilbertson, R. Nodari, W. C. Johnson, S. R. Temple, D. Mandala, A. B. C. Mkandawire, and P. Gepts, 1995: Characterization of variability in the fungus Phaeoisariopsis griseola suggests coevolution with the common bean (Phaseolus vulgaris). Phytopathology 85, 600-607.

McDermott, J. M., 1993: Gene flow in plant pathosystems. Annu. Rev. Phytopathol. 31, 353-373.

Nelson, R. R., 1978: Genetics of horizontal resistance to plant diseases. Annu. Rev. Phytopathol. 16, 359-378.

Saettler, A. W., and V. F. Correa, 1984: Angular Leaf Spot (Isariopsis griseola) in seed fields of Michigan Red Kidney Beans. Annu. Rep. Bean Improve. Coop. 27, 29-30.

Schmit, V., P. du Jardin, J. P. Baudoin, and D. G. Debouck, 1993: Use of chloroplast DNA polymorphisms for the phylogenetic study of seven Phaseolus taxa including Phaseolus vulgaris and Phaseolus coccineus. Theor. Appl. Genet. 87, 506-516.

Schwartz, H. F., V. F. Correa, P. A. D. Pineda, M. M. Otaya, and M. J. Katherman, 1981: dry bean yield losses caused by Ascochyta, angular and white leaf spots in Colombia. Plant Dis. 65, 494- 496.

__ - M. A. Pastor Corrales, and S. P. Singh, 1982: New sources of resistance to anthracnose and angular leaf spot of beans (Phaseolus vulgaris L.). Euphytica 31, 741-754.

Singh, A. K., and S. S. Saini, 1980: Inheritance of resistance to angular leaf spot (Isariopsis griseola Sacc.) in French bean (Phaseolus vulgaris L.). Euphytica 29, 175-176.

Srivastava, L. S., D. K. Gupta, K. R. Dhiman, and G. Singh, 1995: Source of resistance in French bean (Phaseolus vulgaris) to angular leaf-spot (Phaeoisariopsis griseola) in Sikkim. Indian J. Agricult. Sci. 65, 305-307.

Wehner, T. C., and N. Shetty, 1997: Downy mildew resistance of the cucumber germplasm collection in North Carolina field tests. Crop Sci. 37, 1331-1340.

Welsh, M. M., and K. F. Grafton, 1997: Identifying genes for resistance to common bacterial blight of bean. Annu. Rep. Bean Improve. Coop. 40, $104-105$.

Young, R. A., and J. D. Kelly, 1996: Characterization of the genetic resistance to Colletotrichum lindemuthianum in common bean differential cultivars. Plant Dis. 80, 650-654. 